\title{
Blood urea changes in hypertensive patients according to therapy given, blood pressure control, and serum potassium levels
}

\author{
C. J. Bulpitt \\ From M.R.C. Clinical Pharmacology Research Group, Royal Postgraduate Medical School; \\ and the Chronic Disease Control Study Unit, Department of Public Health, \\ London School of Hygiene and Tropical Medicine
}

The annual increase in blood urea was determined in 253 patients attending a hypertension clinic. In twothirds of patients there was a rise in blood urea during treatment, which was not related to blood pressure control when measured in the standing position, or to the level of serum potassium. The blood urea level was increased during guanethidine administration but this appeared reversible on stopping treatment. Methyldopa and reserpine therapy did not increase the blood urea, and diuretics and bethanidine produced only minor nonsignificant changes. These findings are discussed in relation to the different actions of these hypotensive agents.

It is important to monitor renal function in hypertension, as renal failure accounts for up to 30 per cent of the deaths in hypertensive patients treated in hospital (Breckenridge, Dollery, and Parry, 1970). The retrospective investigation to be described was carried out to determine the effect of blood pressure control, therapy given, and serum potassium on renal function in patients attending the Hammersmith Hospital hypertension clinic.

\section{Methods}

The records of all patients attending the Hammersmith clinic were examined for a 3-month period. If a patient had attended the clinic for more than 5 years and had at least 4 estimations of blood urea, the annual increment in blood urea was computed. The method of estimating the increment in blood urea is being described in detail elsewhere (Bulpitt, 1974).

The patients had been followed for a mean of 7 years with, on average, 12 blood urea measurements. These measurements were distributed lognormally and therefore the logarithm of blood urea was employed in the calculations. Many patients had more than one estimation of blood urea in a calendar year, in which case the average $\log$ urea was calculated for each year a patient was followed. The annual increment in this log urea was calculated for each patient using a linear regression technique.

The average serum potassium was computed for each year, provided measurements were available for at least 4

Received II September 1973. years and excluding a small number of patients with asthma who were receiving steroid therapy. The mean of the yearly serum potassium results for a patient gave the average level of serum potassium for that patient.

A subset of II9 patients who attended over a 6-week period had a record made of all previous standing blood pressure measurements, excluding the year of presentation to the clinic, in order to give an estimate of the influence of blood pressure control. The average standing systolic and diastolic pressures were computed for each calendar year, excluding the year the patient first attended the clinic, and from these results average systolic and diastolic pressures were calculated for the whole followup period. The average log blood urea for each patient was also computed using all the blood urea measurements for that patient. Diagnoses, average age during follow-up, and details of therapy given were recorded. Therapy was subdivided into drugs given for more than two-thirds of the study period and drugs given for less than this time. Blood urea was estimated by the diacetyl monoxime method and the serum potassium by flame photometry, all measurements being made on plasma samples in the Department of Chemical Pathology, Royal Postgraduate Medical School. All blood pressures had been taken using a standard mercury manometer, after about one minute in the standing position, and the diastolic blood pressure almost always was taken at the point of muffing ofsound.

\section{Results}

The records of 253 patients were studied. One hundred and seventy-six patients had essential hypertension (90 women, $86 \mathrm{men}$ ) and 77 were 
TABLE I Results according to whether therapy was given for more than two-thirds of study period, or not given at any time; both men and women and essential and 'secondary' hypertension

\begin{tabular}{|c|c|c|c|c|c|c|c|c|c|c|}
\hline \multirow[t]{2}{*}{ Therapy } & \multicolumn{2}{|c|}{ Methyldopa } & \multicolumn{2}{|l|}{ Diuretic } & \multicolumn{2}{|c|}{ Guanethidine } & \multicolumn{2}{|l|}{ Reserpine } & \multicolumn{2}{|c|}{ Bethanidine } \\
\hline & Taken & $\begin{array}{l}\text { Not } \\
\text { taken }\end{array}$ & Taken & $\begin{array}{l}\text { Not } \\
\text { taken }\end{array}$ & Taken & $\begin{array}{l}\text { Not } \\
\text { taken }\end{array}$ & Taken & $\begin{array}{l}\text { Not } \\
\text { taken }\end{array}$ & Taken & $\begin{array}{l}\text { Not } \\
\text { taken }\end{array}$ \\
\hline $\begin{array}{l}\text { Average blood } \\
\text { urea }(\mathrm{mg} / \mathrm{roO} \mathrm{ml}) \\
\text { No. }\end{array}$ & $\begin{array}{l}38 \cdot 46 \\
107\end{array}$ & $\begin{array}{l}38 \cdot 83 \\
73\end{array}$ & $\begin{array}{l}38 \cdot 67 \\
183\end{array}$ & $\begin{array}{l}35 \cdot 56 \\
24\end{array}$ & $\begin{array}{l}46 \cdot 83 \\
30\end{array}$ & $\begin{array}{l}37 \cdot 35 \\
207\end{array}$ & $\begin{array}{l}34 \cdot 99 \\
22\end{array}$ & $\begin{array}{l}38 \cdot 79 \\
189\end{array}$ & $\begin{array}{l}40 \cdot 95 \\
16\end{array}$ & $\begin{array}{l}38 \cdot 66 \\
196\end{array}$ \\
\hline $\begin{array}{l}\text { Average annual } \\
\text { increment in } \\
\text { log urea } \\
\text { No. }\end{array}$ & $\begin{array}{l}0.00670 \\
107\end{array}$ & $\begin{array}{l}0.00713 \\
73\end{array}$ & $\begin{array}{l}0.00578 \\
183\end{array}$ & $\begin{array}{l}0.00620 \\
24\end{array}$ & $\begin{array}{l}0.00954 \\
30\end{array}$ & $\begin{array}{l}0.00650 \\
207\end{array}$ & $\begin{array}{l}0.00312 \\
22\end{array}$ & $\begin{array}{l}0.00724 \\
189\end{array}$ & $\begin{array}{l}0.00657 \\
16\end{array}$ & $\begin{array}{l}0.00606 \\
196\end{array}$ \\
\hline $\begin{array}{l}\text { Average systolic } \\
\text { blood pressure } \\
\text { (mmHg) } \\
\text { No. }\end{array}$ & $\begin{array}{c}152 \cdot 0 \\
50\end{array}$ & $\begin{array}{c}150 \cdot 2 \\
36\end{array}$ & $\begin{array}{c}152 \cdot 3 \\
87\end{array}$ & $\begin{array}{c}149 \cdot I \\
9\end{array}$ & $\begin{array}{c}161 \cdot 8 \\
16\end{array}$ & $\begin{array}{c}150 \cdot 9 \\
94\end{array}$ & $\begin{array}{c}149 \cdot 4 \\
12\end{array}$ & $\begin{array}{c}152 \cdot 7 \\
83\end{array}$ & $\begin{array}{c}158 \cdot 3 \\
6\end{array}$ & $\begin{array}{c}\text { I } 52 \cdot 5 \\
96\end{array}$ \\
\hline $\begin{array}{l}\text { Average diastolic } \\
\text { blood pressure } \\
\text { (mmHg) } \\
\text { No. }\end{array}$ & $\begin{array}{l}95 \cdot I \\
50\end{array}$ & $\begin{array}{l}92 \cdot 3 \\
36\end{array}$ & $\begin{array}{l}94 \cdot 8 \\
87\end{array}$ & $\begin{array}{c}92 \cdot 6 \\
9\end{array}$ & $\begin{array}{l}95 \cdot 3 \\
16\end{array}$ & $\begin{array}{l}94 \cdot 3 \\
94\end{array}$ & $\begin{array}{l}91 \cdot 8 \\
12\end{array}$ & $\begin{array}{l}94 \cdot 5 \\
83\end{array}$ & $\frac{94 \cdot 3}{6}$ & $\begin{array}{l}93 \cdot 9 \\
96\end{array}$ \\
\hline
\end{tabular}

Blood urea measurements for the whole three-month sample.

, pressure ," for the subset attending over 6 weeks.

judged to have secondary hypertension ( 44 women, 33 men).

\section{Effect of therapy}

Table I summarizes the first analysis. The patients were divided into those who had never received a particular therapy and those who received the therapy for more than two-thirds of the follow-up time. When compiling this Table, drug combinations were allowed and patients receiving one drug were often receiving other hypotensive agents as well. The average blood urea, annual increment in log urea, and systolic and standing diastolic pressures are listed. The number of patients contributing to each result is also given.

The average blood urea was moderately raised in the group receiving guanethidine compared with the group not receiving this drug $(46.8 \mathrm{mg} / 100 \mathrm{ml}$ against $37.4 \mathrm{mg} / 100 \mathrm{ml} ; \mathrm{P}<0.01$ ). The guanethidine group also had a significantly raised standing systolic pressure (I6I.8 $\mathrm{mmHg}$ against $150.9 \mathrm{mmHg}$; $P<0.01$ ), and the annual increase in log blood urea was highest in this group ( 0.0095 per annum), but not significantly different from the group not receiving guanethidine ( 0.0065 per annum). The average blood urea while taking methyldopa, 38.5 $\mathrm{mg} / 100 \mathrm{ml}$, a diuretic, $38.7 \mathrm{mg} / 100 \mathrm{ml}$, reserpine $35.0 \mathrm{mg} / 100 \mathrm{ml}$, and bethanidine $41 \cdot 0 \mathrm{mg} / 100 \mathrm{ml}$, were not significantly different from the groups not taking these drugs. Similarly the mean log urea incre- ments for these drug groups were not significantly different from the corresponding comparison groups.

Considering only patients who received guanethidine, $18 \mathrm{had}$ at least 3 blood urea measurements both before and during guanethidine therapy, and 7 had at least 3 measurements of blood urea both during and after guanethidine therapy. The 18 patients showed an average rise in blood urea of II. I $\mathrm{mg} / \mathrm{IOO} \mathrm{ml}$ after receiving guanethidine which was significant at the $I$ per cent level. The 7 patients showed a non-significant fall in blood urea of $2 \cdot 2 \mathrm{mg} /$ $100 \mathrm{ml}$ on stopping guanethidine. Using all the blood urea results in patients given guanethidine, there were 144 measurements before the drug was started, giving an average of $36.3 \mathrm{mg} / 100 \mathrm{ml} ; 375$ measurements during guanethidine therapy, average $51 \cdot 3 \mathrm{mg} / \mathrm{r} 00 \mathrm{ml}$, and 77 measurements after stopping guanethidine, average $40.2 \mathrm{mg} / 100 \mathrm{ml}$.

\section{Effect of serum potassium level}

Table 2 gives the mean blood urea for each sex according to the average level of serum potassium. The average blood urea in female patients was lower than in male patients and was independent of the level of serum potassium. Similarly, there was no significant relation between the male average blood urea and the average serum potassium.

There is circumstantial evidence that potassium depletion may predispose to pyelonephritis (Muehrcke and McMillan, I963; Woods et al., 
TABLE 2 Blood urea and annual increment in log urea according to the level of the serum potassium; all patients with essential hypertension

\begin{tabular}{llllll}
\hline \multicolumn{5}{c}{ Average serum potassium $(m N)$} \\
\cline { 2 - 6 } & $\leqslant 3.4$ & $3.4-3.9$ & $4 \cdot 0-4.4$ & $4.5-4.9$ & $>4.9$ \\
\hline Average blood urea (females) & 34.0 & 32.2 & 35.8 & 32.9 & \\
No. & 13 & 44 & 40 & 7 & \\
Average blood urea (males) & 37.5 & 38.4 & 39.5 & 32.1 & 28.2 \\
No. & 4 & 45 & 34 & 6 & 1 \\
Annual log urea increment & 0.0064 & 0.0093 & 0.0081 & -0.0006 & -0.0257 \\
No. & 17 & 89 & 74 & 13 & 1 \\
\hline
\end{tabular}

1959), and cause both tubular damage and chronic renal disease in rats (Fourman, McCance, and Parker, 1956). The groups with a low serum potassium during follow-up were therefore examined for evidence of an increased annual increment in log blood urea (Table 2). There was no above average increment in the 17 patients with an average serum potassium equal to or less than $3.4 \mathrm{mN}$, and no significant increase in urea increment for 89 patients with an average serum potassium between 3.5 and $3.9 \mathrm{mN}$. The group with a relatively high mean serum potassium of 4.5 to $4.9 \mathrm{mN}$ did not show, on average, a positive annual increment in blood urea, but this group contained only 13 patients.

\section{Effect of blood pressure control}

Table 3 gives the correlation coefficient between annual log urea increment and the standing diastolic and systolic blood pressure for the four groups, male and female, essential and 'secondary' hypertension. There was no significant positive linear relation

TABLE 3 Correlation coefficient between annual log urea increment and standing diastolic and systolic blood pressure; all II 9 patients with computed average standing blood pressure

\begin{tabular}{|c|c|c|c|}
\hline \multirow{2}{*}{$\begin{array}{l}\text { Sex and type } \\
\text { of hypertension }\end{array}$} & \multirow[t]{2}{*}{ No. } & \multicolumn{2}{|c|}{ Correlation coefficient } \\
\hline & & $\begin{array}{l}\text { Standing diastolic } \\
\text { blood pressure }\end{array}$ & $\begin{array}{l}\text { Standing systolic } \\
\text { blood pressure }\end{array}$ \\
\hline $\begin{array}{l}\text { Female } \\
\text { essential } \\
\text { Female }\end{array}$ & 4I & $0 \cdot 26$ & 0.09 \\
\hline $\begin{array}{l}\text { 'secondary' } \\
\text { Male }\end{array}$ & 23 & 0.31 & 0.22 \\
\hline $\begin{array}{l}\text { essential } \\
\text { Male }\end{array}$ & 39 & $0 \cdot 18$ & -0.11 \\
\hline 'secondary' & 16 & -0.08 & 0.23 \\
\hline
\end{tabular}

between standing blood pressure and annual log urea increment for any of these four groups or for the total group of 119 patients, and, therefore, no strong evidence that the level of standing blood pressure influenced the rate of increase in blood urea.

\section{Discussion}

The blood urea is a less satisfactory index of glomerular filtration rate than, say, creatinine clearance, because the blood urea varies with diet (MacKay and MacKay, 1927), and urea diffuses out of the renal tubules. However, the estimation of blood urea was routinely made during the years of study, and many patients were on methyldopa which renders autoanalyser results inaccurate for urinary creatinine and possibly plasma creatinine measurements (Madocks et al., 1973). The blood urea measurements should therefore have given a worthwhile estimate of glomerular filtration in this longterm study on hypertensive patients.

Two-thirds of the treated patients with essential hypertension had an increase in blood urea with time, and increases with age found in the normal population may be of a somewhat lower order of magnitude than in these hypertensive patients (Bulpitt, 1974; Lewis and Alving, 1938; Josephson and Dahlberg, 1952).

Certified deaths from hypertensive heart disease and malignant hypertension have been steadily falling in England and Wales but not those from hypertensive renal disease (Registrar General, 1973). It is, therefore, relevant that this study failed to demonstrate a significant positive relation between the standing blood pressure in treated patients and the rise in blood urea, especially as the average standing systolic pressure ranged from 120 to $193 \mathrm{mmHg}$ and the diastolic pressure from 76 to $116 \mathrm{mmHg}$. The relation between the lying blood pressure and the increase in blood urea remains to be determined. 
The excessive rise in blood urea in treated hypertensives could not be explained on the basis of hypokalaemia. In all, 229 patients received a potassium-losing diuretic for some of their follow-up period and 170 received potassium supplements. In spite of potassium therapy, the mean of the serum potassium level was only $3.8 \mathrm{mN}$, and 17 patients had an average serum potassium of less than $3.5 \mathrm{mN}$. It was reassuring that at these levels of serum potassium there was no evidence of an excessive rise in blood urea.

The only drug associated with a higher than average increase in blood urea was guanethidine. Guanethidine has been reported to produce a fall in blood urea in 60 per cent of cases (Bhatt and Naik, I966); a slight rise in most cases with a normal presenting blood urea but a fall in patients presenting with a high blood urea (Singh and Haritwal, r965a); a rise in 58 per cent of patients (Leishman and Sandler, 1967); a fall in 20 per cent of patients and no mention of any increases (Mehta, Bansal, and Gupta, 1965); and an average fall in blood urea of $22 \mathrm{mg} / 100 \mathrm{ml}$ in 14 patients with hypertension and hypertensive heart failure (Singh and Haritwal, I965b). Guanethidine and other adrenergic neurone blocking drugs lower both the cardiac output and renal blood flow in the upright position. The postural drop in blood pressure on changing from the lying to the standing position is greater with guanethidine than with bethanidine or methyldopa (Bulpitt and Dollery, 1973), possibly giving a greater fall in renal blood flow on assuming the standing position. This postural change in renal blood flow may explain the result of this survey. The patients who received guanethidine showed no significant difference in age, average serum potassium level, or standing diastolic blood pressure from the patients who did not receive this drug. The standing systolic blood pressure was relatively high in the guanethidine group, but this probably indicates a difference in action of guanethidine, rather than providing any evidence that the guanethidine group was different from the groups receiving other potent hypotensive agents such as methyldopa or bethanidine. The data presented indicated that any impairment of renal function with guanethidine was probably reversible on stopping treatment. A larger survey would be required to demonstrate any increase in blood urea on giving a diuretic or bethanidine. Methyldopa has been reported to reduce renal vascular resistance when given intravenously (Onesti et al., 1962), but was not associated with any reduction in blood urea in this survey.

I am indebted to Professor I. Wootton and his department of Chemical Pathology where all the biochemical tests reported in this survey were carried out, and to Professor C. T. Dollery and Dr. A. Breckenridge for making it possible for this survey to be made on the records of their patients.

I am also indebted to Miss Aviva Petrie for statistical advice; to Miss Margaret Chandler, Mrs. Patricia Lipscomb, and Miss Rosalind Catling for much computing and programming assistance; and to Miss S. Jackson for help with data collection. Some of these data were presented in a dissertation towards the degree of M.Sc. (Medical Statistics) of the University of London.

\section{References}

Bhatt, J. L., and Naik, C. H. (1966). Guanethidine as a hypotensive agent. Fournal of the Indian Medical Profession, 12, 5633.

Breckenridge, A., Dollery, C. T., and Parry, E. H. O. (1970). Prognosis of treated hypertension. Quarterly fournal of Medicine, 39, 4I I.

Bulpitt, C. J. (1974). The increase in blood urea in hypertensive patients - a longitudinal study. In preparation.

Bulpitt, C. J., and Dollery, C. T. (1973). Side effects of hypotensive agents evaluated by a self-administered questionnaire. British Medical fournal, 3, 485 .

Fourman, P., McCance, R. A., and Parker, R. A. (1956). Chronic renal disease in rats following a temporary deficiency of potassium. British fournal of Experimental Pathology, 37, 40.

Josephson, B., and Dahlberg, G. (1952). Variations in the cellcontent and chemical composition of the human blood due to age, sex and season. Scandinavian fournal of Clinical and Laboratory Investigation, 4, 216.

Leishman, A. W. D., and Sandler, G. (1967). Guanethidine and hypertension after five years. Angiology, 18, 705 .

Lewis, W. H., and Alving, A. F. (1938). Changes with age in the renal function in adult men. American fournal of Physiology, 123, 500.

MacKay, E. M., and MacKay, L. L. (1927). The concentration of urea in the blood of normal individuals. Fournal of Clinical Investigation, 4, 295.

Madocks, J., Hann, S., Hopkins, M., and Coles, G. A. (1973). Effect of methyldopa on creatinine estimation. Lancet, $I$, I57.

Mehta, R. S., Bansal, H. S., and Gupta, S. R. (1965). Guanethidine and cyclopenthiazide in the treatment of hypertension. Fournal of the Indian Medical Association, 45, 426.

Muehrcke, R. C., and McMillan, J. C. (1963). The relationship of 'chronic pyelonephritis' to chronic potassium deficiency. Annals of Internal Medicine, 59, 427.

Onesti, G., Brest, A. N., Novak, P., and Moyer, J. H. (1962). Pharmacodynamic effects and clinical use of alpha methyldopa in the treatment of essential hypertension. American fournal of Cardiology, 9, 863.

Registrar General (1973). Statistical Review of England and Wales for the Year I97I, p. 26. H.M.S.O., London.

Singh, D., and Haritwal, A. K. (1965a). Observations on blood urea levels in severe hypertension (with reference to guanethidine and adjuvant therapy). Current Medical Practice, 9, 2 10.

Singh, D., and Haritwal, A. K. (1965b). Hypertensive heart failure with special reference to guanethidine therapy. Current Medical Practice, 9, 333.

Woods, J. W., Welt, L. G., Hollander, W., and Newton, M. (1959). Susceptibility to experimental pyelonephritus during and after potassium depletion. Fournal of Clinical Investigation, 38, 1056.

Requests for reprints to Dr. C. J. Bulpitt, Chronic Disease Control Study Unit, 3 I Bedford Square, London WCIB $3 E L$. 